\title{
What is Law \& Economics and How Could It Have Contributed to Preventing the Global Crisis?
}

\author{
Jacek Lewkowicz
}

\begin{abstract}
A B S T R A C T
Objective: The main goal of the article is to investigate the underpinnings and research apparatus of law \& economics, as well as to expose its relevance to economists and lawyers in the context of the recent global financial crisis and preventing future crashes.

Research Design \& Methods: The research objective is met with the usage of the analysis of the primary material and theoretical inquiry. The article covers theoretical dimensions of the application of law \& economics to the analysis of market problems, such as the global financial crisis.
\end{abstract}

Findings: A crucial advantage of law \& economics is its mix of research apparatus economic and legal theory, as well as econometric and behavioural approaches. A detailed analysis of institutions shall enable more precise assessment of the outcome of market phenomena. The causes of the recent global financial crisis could have been addressed by research in law \& economics. Popularisation of law \& economics may contribute to preventing crises.

Implications \& Recommendations: A deep inquiry of market phenomena relies on interdisciplinary research. Applying legal-dogmatic research to formal institutions and combining it with empirical economic analysis could lead to better understanding of market issues, like crises.

Contribution \& Value Added: The article highlights the importance of law \& economics for dealing with market failures. Its core value added is the popularisation of this interdisciplinary approach and description of possible applications.

Article type: conceptual paper

Keywords: law \& economics; institutional economics; global crisis

JEL codes: K10, K20, G01

Received: 23 January $2018 \quad$ Revised: 26 April $2018 \quad$ Accepted: 6 June 2018

\section{Suggested citation:}

Lewkowicz, J. (2018). What is Law \& Economics and how could it have contributed to preventing the Global Crisis?. Entrepreneurial Business and Economics Review, 6(3), 89-101. https://doi.org/10.15678/EBER.2018.060306 


\section{INTRODUCTION}

Market phenomena, such as financial crises, tend to turn away from strict assumptions of neoclassical models. Their outcomes affect organisations, households, individuals and states. Effects of market failures or even crises are multidimensional and may have both economic, sociological, or psychological character. Such market events relate to regulation. Sometimes suboptimal regulation leads to crises. One of the approaches towards the analysis of relationships between legal rules and economics is law \& economics with its well-developed research apparatus relying on economic theory as well as econometric tools.

The article covers theoretical dimensions of the application of law \& economics to the analysis of market problems, such as the global financial crisis. The key objective of the article is to review the underpinnings and research apparatus of law \& economics, as well as to expose its relevance to economists and lawyers in the context of preventing future crises. The research objective is met with the usage of the analysis of the primarily material and theoretical inquiry. By this research we aim to provide a value-added to the broad and actual discussion over regulations regarding markets.

The article is organised as follows: it discusses general principles of law \& economics, the research apparatus of law \& economics, as well as law \& economics in the context of the global financial crisis.

\section{LITERATURE REVIEW}

\section{Origin and Evolution of Law and Economics}

Law \& economics is concentrated on relations between economics and law - mostly by analysing the law with economic research tools. Law \& economics is classified in different ways. Sometimes it is treated as a subdomain of economics (Rowley, 2005), research movement (Posner, 1987), or a separate branch of science, without stating its roots (Coase, 1993). Although classification issues are still debated, law \& economics is dynamically developing.

Some of the most notable precursors of law \& economics were i.a. N. Macchiavelli, T. Hobbes, Ch. Wolff, C. Beccaria, D. Hume, A. Smith and J. Bentham (Mackaay, 2000). They dealt with non-market, but still economic aspects of human behaviour (Posner, 2005). However, some of the first successful attempts of regular analysis of legal institutions with the usage of economic apparatus were conducted in 19th century (Bełdowski \& Metelska-Szaniawska, 2007).

The first wave of research on law \& economics occurred around the middle of 19th century and its core idea was that regulations are dependent inter alia on economic circumstances and individual rights may be distinguished from collective resources (Bełdowski \& Metelska-Szaniawska, 2007). In addition, the significance of evolution of institutions was commented. Representatives of the so-called first wave of law \& economics were focused mainly on the analysis of benefits and costs from the perspective of economic actors facing scarcity of resources. American institutionalism of the end of 19th century, in turn, was concentrated on interrelationships between economic processes and legal issues. This approach gained its reputability in the 1920s and 1930s, also thanks to attempts to formulate research perspectives alternative to neoclassical modelling 
(Bełdowski \& Metelska-Szaniawska, 2007). Some of the key representatives of the classical institutionalism were T. Veblen, J.R. Commons and W.C. Mitchell. They managed to challenge some of the strict assumptions and tendencies widespread in neoclassical economics, such as autonomous market mechanism, static analysis, mathematical formalism, market self-regulation and separation of economic problems from cultural or social background (Wilkin, 2004). However, due to methodological weaknesses, classical institutionalism was not a leading economic approach of its times.

The first modern school of law \& economics evolved at the University of Chicago. Thanks to efforts of H. Simons, F.A. Hayek and others, legal courses covered also economic readings (Mercuro \& Medema, 2006). In the late 1950s The Journal of Law \& Economics was set up. Apart from R. Coase, interdisciplinary research in economics and law was conducted among others by G. Becker and R. Posner. Becker employed economic apparatus to his analysis of crime, addiction, or discrimination (Becker, 1968). Posner made a crucial point about economic aspects of a deterrent role of legal sanctions and referred to rational approach undertaken by criminals (Posner, 1973). The aspect of deterrence is closely linked with the general issue of respecting the laws, which in fact establish a normative system that is usually being constructed by legislators in order to develop social interactions (Chauvin, Stawecki, \& Winczorek, 2011). Deterrence incentives enhance the society to act in line with the disposition stated in the hypothesis of the legal norm. The Chicago school of law \& economics produced a positive approach as well as a normative perspective (Mercuro \& Medema, 2006).

A significant role for the evolution of law \& economics was performed by the New Haven school, which was represented i.a. by G. Calabresi. His contributions include the distinction of direct costs of accidents, costs of inadequate compensation of losses and administrative costs. He and his followers were working on general deterrence and specific deterrence instruments (Calabresi, 1970). In addition, Calabresi considered also issues like income redistribution and allocation of risk (Priest, 2005). The New Haven school of law \& economics explicitly refers to achievements of the Chicago school, with a special stress put on reduction of market failures by imposing optimal regulations (Katz, 1998). The New Haven school is commonly recognized as a normative one (Bełdowski \& Metelska-Szaniawska, 2007).

Another approach towards law \& economics is the functionalism of the Virginia school. To a large extent it is based on the public choice theory. Public choice theory, in turn, is focused on non-market mechanisms of making decisions or economic analysis of politics (Wilkin, 2005). The Virginia school of law \& economics applies the model of rational choice to the analysis of politics and law. Some of the most notable representatives of this school were J.M. Buchanan and G. Tullock (Buchanan \& Tullock, 1962). Public choice theory assumes rationality of political actors. Another key assumption of functional approach towards law \& economics is normative individualism. It means that the analysis of law is in this context based on investigation of the structure of institutional incentives (Parisi, 2004).

The institutional school of law \& economics is perceived as a branch of institutional economics or new political economy (Buchanan, 1989). Indeed, it is strongly related to new institutional economics developing since 1970s. New institutional economics enriches neoclassical theory with institutional aspects. The scope of institutional research is very broad. Some of its key interests are: contractual analysis, property rights, or the economic role of the state (Bełdowski \& Metelska-Szaniawska, 2007). Institutional law \& economics 
covers issues like efficiency or effectiveness of regulations, legal order, institutional equilibrium, evolution of legal institutions (Medema \& Mercuro, 2000). The core interest of institutional law \& economics is the interrelationship between legal regulations and the economy. Naturally, the abovementioned approaches do not stand for a complete list, but they may be treated as the leading perspectives of law and economics.

\section{MATERIAL AND METHODS}

\section{Research Apparatus of Law and Economics}

Law \& economics allows researchers to apply the theoretical underpinnings from institutional economics and regulatory economics to the case of a particular market.

The beginnings of law \& economics were generally theoretical. Scholars adapted theorems, concepts, and research methods from economics in order to reveal an economic rationale of regulations. It turned out that formal models could relate economic outcomes to the institutional environment. Those fields of scholarship dealt with crime, contracts, property rights, torts, trials and other spheres.

Over the years, the theoretical approach in law \& economics faced diminishing returns, probably because of the shrinking of remaining areas of law to be analysed. This pushed some extent scholars to switch into empirical, quantitative analysis of law, a very attractive frontier in economic analysis of regulations. Some data exist in rudimentary forms or have to be scraped, but more data sources are becoming available for quantitative law \& economics, which provides data-driven conclusions useful for policymakers and economic agents. From a methodological point of view, advanced econometric tools may be applied in law \& economics research. However, scarcity of data often limits the scope of empirical analyses.

Law \& economics focuses importantly on transaction costs economics (Bełdowski \& Metelska-Szaniawska, 2007). Basic theoretical underpinnings were provided i.a. by R. Coase, who stressed out the importance of transaction costs of exchange and provided the foundation for the remarkable insight that has come to be known as the Coase Theorem (Coase, 1960). What is crucial from the perspective of law \& economics, even from early studies in institutional economics, is that the state provides a regulatory (institutional) environment that motivates contracts that tend to allocate resources optimally from private initiative. Legal obstacles affecting transactions should be eradicated from the legal system.

An important trend of increasing sophistication of economic tools can be observed in the second part of 20th century. It contributes significantly to the evolution of economics and its various applications. But it may have as a side effect the separation between academic research in economics and the practice of legal studies. Higher degree of economic specialisation and complexity of formalisation of the apparatus become more and more difficult for lawyers to understand. However, economists without any training in law, tend to treat legal institutions cursorily and amateurishly. So the challenge is to merge legal and economic knowledge and tools in one research direction and law \& economics provides the appropriate apparatus to do so. 


\section{Aims of Law and Economics}

One of the most important goals of law \& economics is to seek for a higher effectiveness or efficiency of law (Schaefer \& Ott, 2004). However, the term of effectiveness of law is ambiguous and does not have any common definition. Lawyers claim efficiency of law as a proved potentiality to achieve assumed legislative tasks (Stelmach, Brożek, \& Załuski, 2007). Economists, in turn, treat efficiency of law more broadly - as a capacity to reach assumed goals, but with the minimal usage of resources (Stroiński, 2003).

The economic approach towards legal regulations (formal institutions) is based on an assumption that they should enable the raising of the level of utility of individuals, relating to an improved allocation of resources (Georgakopoulos, 2005). Due to the fact that the effectiveness of law may be differently interpreted, several measures are applied to state the effectiveness of particular institutions - for instance: Pareto, Kaldor-Hicks and Posner criteria (Famulski, 2017). Naturally the aforementioned list of exemplary approaches is not closed and it is difficult to point out a dominant perspective.

The sphere of effectiveness of regulations is much less developed than effectiveness of markets. What is crucial, is that the law is not only assessed by its effectiveness - it encompasses also issues like social justice and others that are tough to be economically expressed (Schaefer \& Ott, 2004). Effectiveness of institutions may assume also maximisation of the difference between social benefits and social costs of implementation of new laws. Some institutions, both formal and informal, can be used as tools for reducing market failures, but not always (Botero, Djankov, La Porta, Lopez-de-Silanses, \& Shleifer, 2004).

Within the existing economic literature, it is relatively common to describe regulations as a substitute for market mechanisms. Regulatory interventionism, accordingly, shall be implemented in order to reach sustainable market rules. Institutions are usually endogenous, which is explained from the perspectives of legal theory, social conflict or effectiveness of institutions. With the approach undertaken in legal studies, market institutions are related to the evolution of the legal system of a state (Botero et al., 2004). Institutions may express interests of groups which seek economic rents. At the same time, the character of institutions does not have to influence social welfare. Institutions may be involved by rent seeking groups, which produces a distorted allocation of assets (Acemoglu \& Johnson, 2005). Thus, institutions serve as a tool for dividing rents. Institutions may be treated as a source of rents by themselves (Saint-Paul, 2000; Blanchard \& Giavazzi, 2003).

Understanding regulations is not unified in economic science. The meaning of regulations depends on the context. Regulating markets occurs when the presence and activity of market agents is conditioned by the adopted system (Black, 2001). Legal regulations may be imposed in order to lower the effects of market failures, as well as to stimulate development of selected sectors and to promote competition. Thus, market regulations should serve as incentives towards approaching the optimal allocation of resources. Especially important are those regulations responsible for imperfect markets and socially important problems (Alexy, 2008).

Legal regulations are formal institutions, by definition. In general, institutions are characterised within the economic literature as systems of established social rules that structure social interactions (Hodgson 2006). They put constraints on decisions and may be permanent or stable (Glaeser, La Porta, Lopez-de-Silanes, \& Shleifer, 2004). According to D.C. North, institutions are certain 'rules of the game', 'humanly devised constrains that 
shape interaction' (North, 1990, p. 3), and encompass both formal and informal systems and enforcement mechanisms. Voigt (2013) emphasizes not only the difference between formal and informal rules but also refers to the issue of their enforcement. According to this perspective, institutions are 'commonly known rules used to structure recurrent interaction situations that are endowed with a sanctioning mechanism' (Voigt, 2013).

Institutions may be brought to life by organisations or groups or individuals (Leftwich \& Sen, 2010). They serve as a predictable structure for economic, social, and political life by shaping people's incentives and decisions, but institutions do not always determine social behaviour, e.g. because of exogenous factors (Leftwich \& Sen, 2010). Institutions change over time as a result of being reformed (Giddens, 1984). It usually takes time for social actors to adapt to a new institutional environment (Williamson, 2000). From the economic perspective, institutions may cause positive or negative effects. The nature of these outcomes depends on the type of behaviour and decisions that institutions legitimise and on the allocation of resources that they cause (Leftwich \& Sen, 2010).

In a broad sense, regulations stand for all forms of influence on the market made by the state. A narrower perspective, in turn, focuses on formal institutions that affect markets (Kahn, 1991). Regulations are used also by the state as a tool in order to optimise and coordinate its responsibilities to the public. All in all, regulations function as a system of incentives imposed i.a. on market agents. If regulations are valid and are executed, they shall affect decisions of organisations and individuals (Viscusi, Vernon, \& Harrington, 2005). Regulations may be a solution to market failures, market inefficiency, or market disequilibrium.

Moreover, regulations are not only related to economic aspects. Legal institutions may be supportive in fulfilling other aims, encompassing social justice. Accordingly, market regulation appears to be a method of intervention of the legislator and is de facto a common feature of markets. However, when it comes to the context of affecting markets, apart from the material content of legal systems, real actions may be undertaken in order to enforce regulations. Furthermore, not all of mechanism design instruments have to be based on existing institutions (Maskin, 2007). The theory of designing mechanisms states that the desired regulatory goals (economic or social) should be identified first. Then, analyses of opportunities of shaping relevant institutions or mechanisms that could lead to fulfilling such goals may be pursued. If opportunities for succeeding in this context exist, potential forms of institutional design may be considered (Maskin, 2007).

A very significant point is not only about the design of institutions, but also about the manner they are implemented. Due to the opportunism of some interest groups, the status quo may be desired. Because of some geopolitical factors, exact effects of new laws are hard to predict precisely. Discrepancies may be linked also with the pace of reforms (Nsouli, Rached, \& Funke, 2005). Sequential implementation of regulations has an advantage of the ability to make gradual social adjustments to formal rules. However, it may also lead to widespread rent-seeking activity of groups established in the previous system. Shock reforms, in turn, bring fast and sometimes radical changes, but leave less space for social adaptation. The optimal manner of regulatory reforms depends on particular circumstances.

\section{Market Failures and Institutions}

Social or market attitudes towards regulation may be driven by the effectiveness of institutions, which usually assumes maximisation the difference between social benefits and 
social costs of implementation of the new laws. Some institutions, either formal or informal, may be used as tools for reducing market failures (Botero et al., 2004). In this context, the most important challenge is the selection of adequate measures of institutional effectiveness. The point is that law \& economics provides appropriate research tools for the analysis of institutional effectiveness.

Representatives of the most recognizable approaches and economic schools agree on the statement that market failures occur (Snowdon \& Vane, 1998). By market failures we usually consider setbacks in allocation and motivation, which are the basic roles of markets. Market failures evolve because of, i.a., incompleteness of markets, information asymmetry, imperfect competition, externalities, public goods undersupply and problems with redistribution of income. In fact, market failures accompany almost all markets, as long as some kind of imperfection is always present. Neoclassical models did not consider market failures, but more recent theories leave no doubt that market failures exist and should be limited. One of the solutions towards market failures is market regulation.

The market may be treated as a special mechanism of coordination of assets and optimisation of their usage (Atkinson \& Stiglitz, 1980). Actors functioning on markets make decisions based upon production factors, supply and demand, with reference to prices of commodities or services, as well as their own specific utility functions. Functioning of perfect markets is mainly up to the pricing mechanism (Robinson, 1934), while imperfect markets bear regulatory interventions in order to obtain higher levels of economic effectiveness, which is crucial from the perspective of social welfare.

According to the literature on the subject of imposing regulations, the existence of market imperfections is not the only reason for regulating them. Another point is that, in some circumstances, regulatory interventions may foster economic growth (Jamal et al., 2004). States have legitimate tools to introduce formal institutions and execute them.

Some market imperfections are negligible, but others seem to be crucial. Market failures are present in many markets and they tend to differ across states and sectors. A great challenge is to manage the issue of economic efficiency and keep a satisfactory level of justice of allocation of assets, by using legal regulations (Stiglitz, 1991). The logic of regulatory intervention of a state is that if markets are not able to reach the equilibrium by themselves and do not converge towards effectiveness, reasonable regulatory policy may correct this state (Baldwin \& Cave, 1999). The following section is devoted to the recent global financial crisis seen through the lens of market failures. Remarks about the potential of law \& economics in preventing such crashes will conclude.

\section{RESULTS AND DISCUSSION}

\section{The Causes of the Global Financial Crisis}

One may wonder why, having such developed research apparatus and scope of interests of economists, lawyers, and other scholars, we did not avoid the latest global financial crisis. It seems that legal professionals were carrying out the creation of specialised and complex financial instruments that finally crashed out.

A crucial point about the recent global economic crisis is that it affected not only the housing sector of the economy, but it rather brought the financial system to its knees. 
Some attribute the severity of the crisis to the behaviour of banks, which had evaded regulatory capital requirements (Acharya \& Richardson, 2009).

Essentially, banks repacked mortgages into mortgage-backed securities. Banks reduced the amount of capital against their loans, which increased their quasi-capacity to provide new loans (Acharya \& Richardson, 2009). The effect was that when the housing bubble burst, the risk of mortgage defaults was concentrated in the involved banks and made them insolvent. It brought down i.a. Lehman Brothers. The magnitude of the financial crash was fuelled by a large decline in lending by commercial banks. Then, it affected the global financial sector.

The previous paragraph deals with the issue of the roots of the financial crisis that evolved in the United States. However, it should be noted that it spread to another countries, also to emerging market economies, and gained a global status. Emerging markets responded strongly and quickly to the situation in the American financial system. Policies undertaken in emerging markets to insulate them from the U.S. crisis aftereffects, proved inadequate in the view of changes in international trade and the credit crunch, causing a sharp decline in financial flows (Dooley \& Hutchison, 2009). Relatively high global risk aversion and foreseen financial market volatility were found as the key factors causing the decrease in international bank flows during the global financial crisis of 2007-2008 (Herrmann \& Mihaljek, 2013). Increased financial integration, as well as dependence on wholesale funding might have given a rise for exaggeration and global spread of the financial crisis (Claessens, Dell'Ariccia, Igan, \& Laeven, 2010).

What happened may be considered a regulatory failure - banks managed to take high risks in order to achieve higher short-term profits, by evading the capital requirements imposed by legislators, who were mainly hoping to mitigate risks present in the financial sector. What happened was not only the collapse of selected investment banks, but rather a systematic failure of the securitisation market.

The crisis was preceded by a kind of a failure of financial institutions that froze up capital markets. When the bubble burst, the supply of capital to creditworthy entities or individuals was significantly reduced and it even intensified the effects of the crisis in the real economy (Acharya \& Richardson, 2009). In fact, mortgages were granted to individuals without factual ability to pay them back. Those mortgages, in turn, were dependent on increases in house prices. Due to securitisation of the mortgages, credit markets were growing rapidly. However, the quality of such loans deteriorated (Berndt \& Gupta, 2008). As a result, some of the securitised mortgages classified as ' $A A A^{\prime}$ ' instruments by rating agencies, because of modelling failures and, possibly, conflict of interests became untradeable 'toxic assets.' Such behaviour was not in line with the general idea of securitisation. Securitisation is performed mainly in order to spread risk. It is usually done by placing large concentrations of risk from financial institutions to small concentrations for disposal to smaller investors. So securitisation enables banks to avoid holding costly capital by selling it off to others - removing loans from balance sheets. During the period directly preceding the crisis, the securitisation was made to reduce the required capital for banks. But the risk remained concentrated in the financial institutions, which became over-leveraged. Moreover, conflict of interests existed in this context, the striving for fees instead of performing an appropriate risk assessment (Acharya \& Richardson, 2009). 
Another aspect of the global crisis that has to be considered is its behavioural character. It is discussed that economists failed in anticipating the financial crisis and even contributed to it by encouraging the policymakers to perceive more stability and risk sharing within the financial sector, that was present in fact (Colander et al., 2009). Behavioural inclinations had an impact on investors, market-supporting entities and even regulatory institutions (Szyszka, 2010).

The Financial Crisis Inquiry Commission (2011) stated that the financial crisis was an avoidable disaster. The crisis was primarily caused by failures in government and financial market regulations, corporate mismanagement and inattentive risk-taking. The key regulatory fault was related to bosh mortgage lending, excessive packaging and sale of loans, as well as hazardous bets on securities backed by the loans. Regulators were blamed for disappointment in requiring big banks to hold appropriate amount of capital to absorb potential losses and dwell dicey practices.

\section{Law and Economics in the Context of the Global Financial Crisis}

With regard to the abovementioned avoidability, special attention shall be devoted even to law \& economics. Research apparatus of law \& economics, as it was described in previous sections, is interdisciplinary and ranges from philosophy of law to quantitative empirical methods. Regulations responsible for expansion of the crisis could have been analysed with the application of legal-dogmatic, functional, institutional and econometric perspectives, so to reveal incentives lying behind the behaviour of agents and to assess the consequences of their decisions. Advantages of law \& economics compared to purely and separate legal or economic investigations are about its ability to cover the whole range of causes of the crisis.

Unfortunately, law \& economics was relatively silent about the regulations determining such instruments and market practices, like the Federal Reserve Act and other relevant issues that allowed the crisis to spread. In the EU there was also a lack of interest in this perspective. However, some exceptions from those observations may be recalled, i.a. Lucian Bebchuk (2008) from Harvard Law School. On the other hand, a lot of attention shall be put to regulations that may limit the risk of more crises in the future.

The problem was a scarce amount of interaction or collaboration between economists and legal scholars. As a result, the response of law \& economics to the latest global financial crisis was slow. Taking into consideration how useful law \& economics may be in predicting market crashes or dealing with their consequences, this research branch should be developed before additional incidents occur. There are serious problems facing markets and societies today and they are relatively complex and structural, in the areas like financial systems or banking. Thus, a lot has to be done in terms of interdisciplinary research helping to assess and prevent future crises.

Not only do we have a need for more research to develop law \& economics, but there are market needs calling for this. Higher popularity of law \& economics will lead to a higher number of researchers, better access to data, and the development of empirical tools, as well as reconsideration of regulation or public policy. What must be developed are not only joint projects carried out by economists and lawyers, but also adequate educational programmes in law \& economics (like the European Doctorate in Law and Economics). Last, but not least, there is a need for preparing long-term series of research on relevant legal, economic, and social issues in order to make them appropriate for law \& economics. 


\section{CONCLUSIONS}

The main goal of the article was to contribute to a better understanding of the character and possible applications of law \& economics, i.a. to the issue of the global financial crisis. Recent cross-disciplinary research regarding the relevance of law \& economics for social sciences combines economics, legal, and political science and reveals its importance. However, some of branches of law \& economics still require development and more sophisticated empirical apparatus in order to deliver data-driven expertise on the efficiency of particular legal regulations and informal institutions.

Applying the proposed approach of linking economic literature with actual studies on financial systems will be useful. The more systematic empirical analysis may allow for formulating more reliable and scientifically-based recommendations on public policies in order to create a formal setting conductive to the optimal functioning of financial systems. It may allow for a more successful quest for the possibly most adequate regulatory programmes in the future responding to the needs of advanced economies, as well as emerging market and developing countries.

\section{REFERENCES}

Acemoglu D., \& Johnson J.A. (2005). Unbounding Institutions. Journal of Political Economics, 113(5), 959-995.

Acharya, V.V., \& Richardson, M. (2009). Causes of the Financial Crisis. Critical Review, 21(2-3), 195-210.

Alexy, R. (2008). On the Concept and the Nature of Law. Ratio Juris, 21(3), 281-299.

Bebchuk, L. (2008). A Better Plan for Addressing the Financial Crisis. The Economists' Voice, 5(5). 1553-3832. https://doi.org/10.2202/1553-3832.1416

Becker, G. (1968). Crime and punishment: an economic approach. Journal of Political Economy, 76(2), 169-217.

Bełdowski, J., \& Metelska-Szaniawska, K. (2007). Law \& Economics - geneza i charakterystyka ekonomicznej analizy prawa. Bank i Kredyt, 10, 51-69.

Berndt, A., \& Gupta, A. (2008). Moral Hazard and Adverse Selection in the Originate-to-Distribute

Model of Bank Credit. Working Paper. Tepper to School of Business. Carnegie Mellon University.

Blanchard, O., \& Giavazzi, F. (2003). Macroeconomic Effects of Regulation and Deregulation in Goods and Labour Markets. The Quarterly Journal of Economics, 118(3), 879-907. https://doi.org/ 10.3386/w8120

Botero, J.C., Djankov, S., La Porta, R., Lopez-de-Silanses, F., \& Shleifer, A. (2004). The Regulation of Labor. The Quarterly Journal of Economics, 119(4), 1339-1382.

Buchanan, J.M. (1989). Constitutional Economics. In J.M. Buchanan (Ed.). Exploration into Constitutional Economics. College Station: Texas A\&M University Press.

Buchanan, J.M., \& Tullock, G. (1962). The Calculus of Consent. Logical Foundations of Constitutional Democracy. Ann Arbor: The University of Michigan Press.

Calabresi, G. (1970). The Costs of Accidents: A Legal and Economic Analysis. New Haven: Yale University Press.

Chauvin, T., Stawecki T., \& Winczorek P. (2011). Wstęp do prawoznawstwa. Warszawa: C.H. Beck. 
Claessens, S., Dell'Ariccia, G., Igan, D., \& Laeven, L. (2010). Cross-country experiences and policy implications from the global financial crisis. Economic Policy, 25(62), 267-293. https://doi.org/ 10.1111/j.1468-0327.2010.00244.x

Coase, R. (1937). The Nature of the Firm. Economica, 4, 386-405.

Coase, R. (1960). The Problem of Social Cost. Journal of Law and Economics, 3, 1-44.

Coase, R. (1993). Law and Economics at Chicago. Journal of Law and Economics, 1, 239-254.

Colander, D., Goldberg, M., Haas, A., Juselius, K., Kirman, A., Lux, T., \& Sloth B. (2009). The financial crisis and the systemic failure of the economics profession. A Journal of Politics and Society, 21(2-3), 249-267. https://doi.org/10.1111/j.1468-0335.1937.tb00002.x

Dooley, M., \& Hutchison, M. (2009). Transmission of the U.S. subprime crisis to emerging markets: Evidence on the decoupling-recoupling hypothesis. Journal of International Money and Finance, 28(8), 1331-1349. https://doi.org/10.3386/w15120

Famulski, T. (2017). Economic Efficiency in Economic Analysis of Law. Finanse i Prawo Finansowe, 3(15), 27-39.

Fukuyama, F. (1997). Zaufanie. Kapitał społeczny a droga do dobrobytu. Warszawa-Wrocław: Wydawnictwo Naukowe PWN.

Georgakopoulos, N.L. (2005). Principles and Methods of Law and Economics. Basic Tools for Normative Reasoning. Cambridge: Cambridge University Press.

Giddens, A. (1984). The constitution of society: Outline of the theory of structuration. University of California Press.

Glaeser, E.L., La Porta, R., Lopez-de-Silanes, F., \& Shleifer, A. (2004). Do Institutions Cause Growth? Journal of Economic Growth, 9(3), 271-303.

Herrmann, S., \& Dubravko, M. (2013). The determinants of cross-border bank flows to emerging markets. Economics of Transition, 21(3), 479-508.

Katz, A. (1998). Foundations of Economic Approaches to Law. New York-Oxford: Oxford University Press.

Leftwich, A., \& Sen, K. (2010). Beyond institutions: Institutions and organizations in the politics and economics of poverty reduction - Thematic synthesis of research evidence. DFIDfunded Research Programme Consortium on Improving Institutions for Pro-Poor Growth (IPPG). University of Manchester.

Mackaay, E. (2000). History of Law and Economics. In B. Bouckaert \& G. De Geest (Eds.). Encyclopedia of Law and Economics. Cheltenham: Edward Elgar.

Maskin, E.S. (2007). Mechanism Design: How to Implement Social Goals. Nobel Prize Lecture.

Medema, S.G., Mercuro, N., \& Samuels, W.J. (2000). Institutional Law and Economics. In B. Bouckaert \& G. De Geest. (Ed.). Encyclopedia of Law and Economics. Cheltenham: Edward Elgar.

Mercuro, N., \& Medema, S.G. (2006). Economics and the Law. From Posner to Post-Modernism and Beyond. Princeton: Princeton University Press.

North, D.C. (1990). Institutions, institutional change, and economic performance. Cambridge: Cambridge University Press.

Nsouli, S.M., Rached, M., \& Funke, N. (2005). The speed of adjustment and the sequencing of economic reforms: Issues and guidelines for policymakers. International Journal of Social Economics, 32(9), 740-766.

Parisi, F. (2004). Positive, Normative and Functional Schools in Law and Economics. European Journal of Law and Economics, 18, 259-272.

Posner, R.A. (1973). Economic Analysis of Law. Boston: Little, Brown \& Co.

Posner, R.A. (1987). The Law and Economics Movement. American Economic Review, 77(2), 1-13. 
Posner, R.A. (2005). The Law and Economics Movement: From Bentham to Becker. In F. Parisi \& Ch. Rowley (Eds.). The Origins of Law and Economics. Essays by the Founding Fathers. CheltenhamNorthampton: Edward Elgar.

Priest, G.I. (2005). The rise of law and economics: a memoir of the early years. In F. Parisi \& Ch. Rowley (Eds.). The Origins of Law and Economics. Essays by the Founding Fathers. CheltenhamNorthampton: Edward Elgar.

Robinson, J. (1934). What is Perfect Competition?. The Quarterly Journal of Economics, 49(1), 104120. https://doi.org/10.2307/1883878

Rowley, Ch. (2005). An Intellectual History of Law and Economics: 1739-2003. In F. Parisi \& Ch. Rowley (Eds.), The Origins of Law and Economics. Essays by the Founding Fathers. CheltenhamNorthampton: Edward Elgar.

Saint-Paul, G. (2000). Understanding labour market institutions. World Economics, 1(2), 73-87.

Schaefer, H.-B., \& Ott, C. (2004). The Economic Analysis of Civil Law. Cheltenham-Northampton: Edward Elgar.

Snowdon, B., \& Vane, H. (1998). Ewolucja współczesnej ekonomii z perspektywy monetarnej (cz. 2. wywiadu z Miltonem Friedmanem). Gospodarka Narodowa, 10.

Stelmach, J., Brożek, B., \& Załuski, W. (2007). Dziesięć wykładów o ekonomii prawa. Warszawa: Wolters Kluwer.

Stroiński, R. (2003). Wprowadzenie do ekonomicznej analizy prawa (law and economics). In M. Bednarski \& J. Wilkin (Eds.). Ekonomia dla prawników i nie tylko. Warszawa: Wydawnictwo Prawnicze LexisNexis.

Szyszka, A. (2010). Behavioral Anatomy of the Financial Crisis. Journal of CENTRUM Cathedra, 3(2), 121-135.

Waldron, J. (1999). The Dignity of Legislation. Cambridge: Cambridge University Press.

Wilkin, J. (2004). Ewolucja ekonomii politycznej i jej miejsce we współczesnej myśli ekonomicznej. In J. Wilkin (Ed.). Czym jest ekonomia polityczna dzisiaj?. Warszawa: Wydawnictwo Wydziału Nauk Ekonomicznych Uniwersytetu Warszawskiego.

Wilkin, J. (2005). Teoria wyboru publicznego - homo oeconomicus w sferze polityki. In J. Wilkin (Ed.). Teoria wyboru publicznego. Wstęp do ekonomicznej analizy polityki i funkcjonowania sfery publicznej. Warszawa: Wydawnictwo Naukowe Scholar.

Williamson, O.E. (2000). The New Institutional Economics: Taking Stock, Looking Ahead. Journal of Economic Literature, 38(3), 595-613.

Viscusi, W.K., Vernon, J.M., \& Harrington, J.E. (2005). Economics of Regulation and Antitrust. Cambridge: The MIT Press.

Voigt, S. (2013). How (not) to measure institutions. Journal of Institutional Economics, 9(1), 1-26. https://doi.org/10.1017/S1744137412000148

The Financial Crisis Inquiry Commission. (2011). The Financial Crisis Inquiry Report. Final Report of the National Commission on the Causes of the Financial and Economic Crisis in the United States. Official Government Edition. 


\section{Authors}

\section{Jacek Lewkowicz}

$\mathrm{PhD}$ in economics (obtained from the University of Warsaw, Poland). His research interests include institutional economics, law \& economics, fiscal policy and digital economy.

Correspondence to: Jacek Lewkowicz, PhD, University of Warsaw, Faculty of Economic Sciences, ul. Długa 44/50, 02-703 Warszawa, Poland; e-mail: jlewkowicz@wne.uw.edu.pl

\section{Acknowledgements and Financial Disclosure}

The views, opinions, findings, and conclusions or recommendations expressed in the article are strictly those of the author.

\section{Copyright and License}

(c) (1) $\Theta$

This article is published under the terms of the Creative Commons

Attribution - NoDerivs (CC BY-ND 4.0) License

http://creativecommons.org/licenses/by-nd/4.0/

Published by the Centre for Strategic and International Entrepreneurship - Krakow, Poland 
